\title{
Evaluating marine reserves as a management policy in the central-southern anchovy (Engraulis ringens) fishery of Chile
}

\author{
Juan Pablo Díaz Vega ${ }^{1}(\mathbb{D})$ \& Yarela Flores Arévalo ${ }^{1,2}(\mathbb{D})$ \\ ${ }^{1}$ Universidad Arturo Prat, Iquique, Chile \\ ${ }^{2}$ Universidad de la Serena, La Serena, Chile \\ Corresponding author: Juan Pablo Díaz Vega (jpdiaz@unap.cl)
}

\begin{abstract}
The anchovy (Engraulis ringens) fishery in central-southern Chile, like many fisheries worldwide, is overexploitation mainly due to poor and short-term management by fishing authorities and communities. This study proposes and evaluates marine reserves as a possible tool to apply since there is a current marine reserve law in Chile. The study's methodology is the simulation of a bioeconomic model that includes two areas: one is the protected, and the other is the artisanal fishing, in which the protected area transfers biomass to the artisanal fishing area. The reserve is incorporated as a decision variable in the management of this resource. It is determined as a percentage of protection of the total fish population related to fishing effort, which quantifies and evaluates the impact of protecting a stock of parental fish on the fishery's sustainability. Biomass data used is from 2000-2006, during which the anchovy fishery was fully exploited. The carrying capacity and intrinsic growth rate are estimated, and biomass is projected at different protection and effort levels. Results show that if a marine reserve with a protection level of $30 \%$ had been applied as a management policy in the anchovy fishery of central-southern Chile in the early 2000s, the fishing activity would be in a state of full exploitation rather than overexploitation as it is today. This model's fundamental contribution is that it makes possible fishery evaluation with real data from the same fishing activity.
\end{abstract}

Keywords: Engraulis ringens; bioeconomic model; fisheries management; anchovy fishery; marine reserve; sustainable development

\section{INTRODUCTION}

For many decades, researchers have recognized that parent stocks are depleting among the world's diverse fisheries, and there has been almost universal agreement that fishery management systems need to be reformed in almost all countries (Hilborn \& Ovando 2014). The anchovy (Engraulis ringens) is an essential resource been depleting in central-southern Chile since 2013 (Porobic et al. 2018, SUBPESCA 2018). A new holistic and sustainable way of managing fisheries is marine reserves (Halpern et al. 2009, Pérez-Ruzafa et al. 2017).

The anchovy is a small pelagic resource that, along with the mackerel (Trachurus murphy) and common sardine (Strangomera bentincki), make up most of the landing of fishing resources in Chile. These fisheries are maintained primarily by individual recruits that renew the species' stock every year during the summer season. Anchovies have a large distributional range in Chile, starting in the extreme north of the Arica and Parinacota region and continuing down through the south's Los Lagos region (Serra 1983). They live mainly along the coast, with a longitudinal distribution up to $30 \mathrm{~nm}$ west in the neritic zone, an area associated with high biologic productivity (Arcos et al. 1987, Arteaga \& Cubillos 2008, Daneri et al. 2000).

Small pelagic species, like the anchovy, frequently experience seasonal fluctuations in their abundance (Bakun 1989) and considerable variability in recruitment (Cubillos \& Arcos 2002, Morales et al. 2003, King \& McFarlane 2005). Their numbers are higher in the summer season (January-February in Chile). Anchovies have a very short life cycle with rapid corporal

Corresponding editor: Federico Cortés 
growth, a high and variable rate of natural death, and a marked spawning season (Serra 1983, Cubillos \& Arancibia 1993b, Cubillos et al. 2001). These factors lead to stock sizes that are largely dependent on recruitment, very unstable, and difficult to estimate (Cubillos \& Arcos 2002). Some authors have classified the pelagic fish population as the most unstable and sensitive population in the face of unregulated fishing (Beverton 1983). This instability, along with the implementation of a variety of administrative and management regulations like closed seasons for reproduction (July-September) and recruitment, highlights how even though this fishery is profitable, it can also be risky and fragile, with high seasonality in fishery landings (Cubillos \& Arancibia 1993a, Pitcher 1995, Cubillos et al. 1998).

Throughout the history of Chilean fisheries has collapsed twice during periods of deregulation. The first and biggest collapse came in 1965 in the northern zone of the country. According to Soto \& Paredes (2018), the myopic public policies on fishing development at the beginning of the 1960s, like the DFL 266 of 1960, Law \#12,937, and Law \#13,039, prompted this resource overexploitation. After only five years, the regulatory and policy incentives intended to develop the industry led to the largest landing in national history-more than one million tones, of which almost 90\% were anchovy (Basulto del Campo 2014). This record landing, combined with the El Niño phenomenon, resulted in one of the biggest collapses of the Chilean fishing industry in the 20th century (Basulto del Campo 2014). The second anchovy collapse between 1972 and 1973, when overexploitation, in conjunction with El Niño, led to an almost $80 \%$ decrease of anticipated catch.

Before the General Fisheries and Aquaculture Law (LGPA by its Spanish acronym) in 1991, which was approved for fishing in a state of full exploitation, which included the anchovy fishery, a phenomenon knew as the "olympic race" occurred, where industrial harvesters invested in more sophisticated fleets to extract a greater portion of the quota. This overinvestment in the industrial fleet resulted in a new record yield for anchovy in 1994 to 2,720,388 t. Aside from depleting the anchovy stock, the "olympic race" also led to Chilean history's biggest mackerel crisis (Basulto del Campo 2014).

In 2001, fishing regulations established a maximum catch limit per fishing ship owner (LMCA by its Spanish acronym) for all principal fishing industries and regulated the artisanal fishers' registry. Since the LMCA has been established, industrial vessels' access in the area reserved for artisanal fishers (the first five nautical miles offshore) has been prohibited. This regulation reduced industrial operations and operative vessels in the artisan fleet more than doubled in this zone from 150 in 2001 to 366 at the beginning of 2010 (Arteaga et al. 2010). It does not mean that the artisanal fleet does the industrial work since they have less fishing power.

When the law established classification levels in 2012 so that scientific-technical committees could evaluate the status of biomass abundance in each fishery, the anchovy has experienced various statuses throughout Chile's different zones. There are three zones in Chile: north (Zone 1), from Arica to Antofagasta $\left(18^{\circ} 28^{\prime} \mathrm{S}, 23^{\circ} 38^{\prime} \mathrm{W}\right.$ to $\left.23^{\circ} 38^{\prime} \mathrm{S}, 70^{\circ} 24^{\prime} \mathrm{W}\right)$; north (Zone 2$)$, from Caldera to Coquimbo $\left(27^{\circ} 8^{\prime} \mathrm{S}\right.$, $70^{\circ} 41^{\prime} \mathrm{W}$ to $30^{\circ} 45^{\prime} \mathrm{S}, 71^{\circ} 0^{\prime} \mathrm{W}$ ); and the centralsouthern (Zone 3), from Valparaíso to Valdivia $\left(33^{\circ} 1^{\prime} \mathrm{S}, 71^{\circ} 37^{\prime} \mathrm{W}\right)$. The most critical zone is the central-southern zone, where anchovy was overexploited from 2013-2018, essentially because of an indiscriminate increase in artisanal fishing (Figure 1).

Anchovy and pelagic fisheries, in general, are managed using mono-specific criteria (Cubillos \& Arcos 2002, Gatica et al. 2007, Porobic et al. 2018), that is, by identifying the status of a resource without considering the ecologic or environmental context in which that resource is found (Caddy \& Sharp 1988, Sepúlveda et al. 2003, Pedraza-Garcia \& Cubillos 2008).

All of the different policies that have been applied to the anchovy fishery have been insufficient. A marine reserve area is an efficient tool for managing fisheries (Sanchirico \& Wilen 2001, Boncoeur et al. 2002, PérezRuzafa et al. 2017) because it allows a stock of fish to be protected from overfishing and it increases the possibility of greater yield in fishing zones (Goñi et al. 2008). Unfortunately, in Chile, the current legislation has not considered marine reserves as a tool in fisheries management.

Marine reserves have been created to conserve marine ecosystems. The idea of having a reserve came in 1912 from of Marcel Hérubel, who developed a theory on them. These were to be spaces protected from fishing that could be used as a fishery management tool (Hérubel 1912). While his ideas were not well-received at the time, they were brought back after the 1980s with publications by Roberts \& Polunin (1991) and Harrison et al. (2012). These authors back Hérubel's theory and provide convincing evidence that has led to a modern theory for designing marine reserves networks. Marine reserves are classified as protected areas by the International Union for Conservation of Nature (IUCN) under category VI of protected areas for resource management. This category of areas aims to preserve the ecosystem, manage commercial fisheries, and 


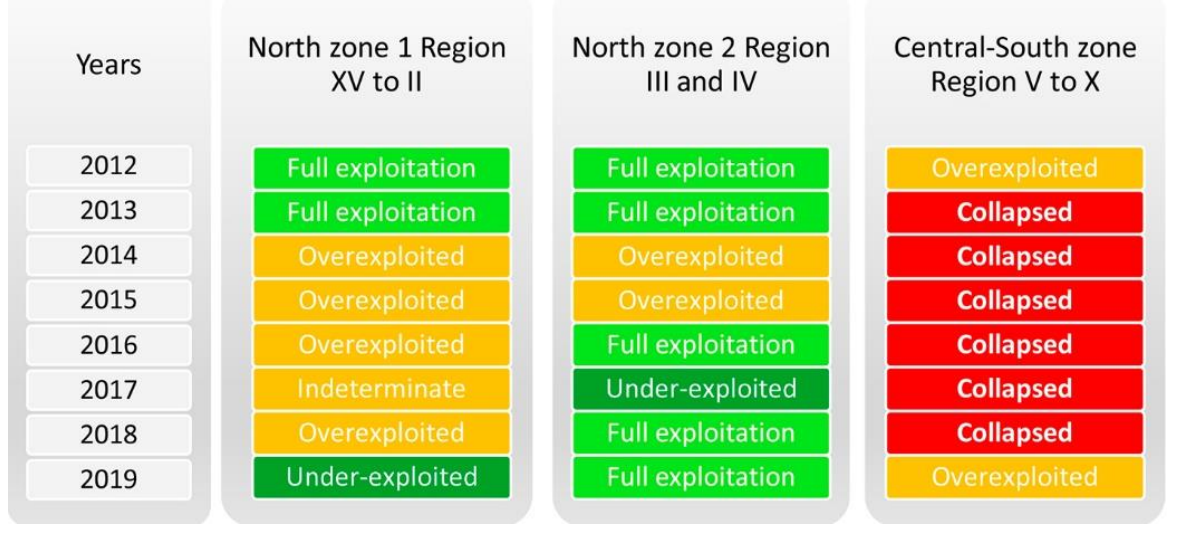

Figure 1. Biomass status levels of the Chilean anchovy (Engraulis ringens) fishery by zones 2012-2019, from the best situation (underexploited) to the worst (over exploited). Source: SUBPESCA (2018).

develop recreational activities. Marine reserves can protect fish resources and aid the artisanal fishing sector.

This study aims to evaluate the hypothetical use of marine reserves in restoring anchovy stocks using a bioeconomic model with data from times when the resource was being overly exploited. In this way, we verify the effects that the reserve would have had on managing the anchovy fishery in the exclusive area to the artisanal fish. Our contribution to the model is to evaluate the fishery from a bioeconomic perspective, considering ecologic aspects and using real data from fisheries. This information can help establish a new form of fishery management in Chile and allow for more sustainable development.

\section{MATERIALS AND METHODS}

In our study, a bioeconomic model was developed, using concepts from the marine reserve theory, we evaluate the impact of the marine reserve as a management policy in the south-central anchovy (Engraulis ringens) fishery in the years before overexploitation based on Díaz \& Salgado (2006) and Cartigny et al. (2008). In Chile, these authors claim that the reserve area for artisanal fishing (ARPA, 5-mile reserve zone) behaves like a marine reserve; even though it does not have that objective, it limits industrial use. They also show that, in the case of northern Chile, ARPA has generated beneficial biological effects in anchovy fishing, allowing the regulator to decide whether to grant or deny the industrial fleet access to the artisanal fishing area. It has been called "perforation windows", considering the natural transfer of biomass from the artisanal patch to the industrial patch.
Table 1. Data used to estimate the anchovy (Engraulis ringens) fishery (2000-2006) carrying capacity. Source: self-elaboration. The data on biomass $(\mathrm{t})$ come from the Instituto de Fomento Pesquero (IFOP 2008).

\begin{tabular}{cccc}
\hline Year & $\mathrm{t}$ & $e^{\wedge}\left(-r^{*} t\right)$ & Total biomass $(\mathrm{t})$ \\
\hline 2000 & 1 & 0.792 & $1,200,000$ \\
2001 & 2 & 0.628 & $1,400,000$ \\
2002 & 3 & 0.497 & $1,800,000$ \\
2003 & 4 & 0.394 & $2,000,000$ \\
2004 & 5 & 0.312 & $2,400,000$ \\
2005 & 6 & 0.247 & $2,700,000$ \\
2006 & 7 & 0.196 & $2,800,000$ \\
\hline
\end{tabular}

We used information from 2000-2006 to estimate the model's parameters, such as the ecosystem's carrying capacity and population growth's intrinsic rate. This period was selected because the fishery was fully exploited with a positive population growth rate, which the fishery has not experienced. Table 1 presents the data with which we estimated the carrying capacity for the anchovy fishery. The study's analysis period is from 2000-2012, using biomass, effort, capture, and capture coefficient.

The population growth rate is estimated in the exponential phase of the curve logistic using Equation

$$
B_{1(2004)}=B_{0(2000)} e^{r t}
$$

were $B$ is the total fish biomass in $t, r$ is the intrinsic growth rate of the parental stock biomass, and $t$ is measured in years.

The exponential model indicates that the population initial size is not relevant; it will continue growing at the populational rate. This situation, in strict rigor, is not effective for fish because there is a limit: the carrying capacity. Because of that, it is necessary to im- 


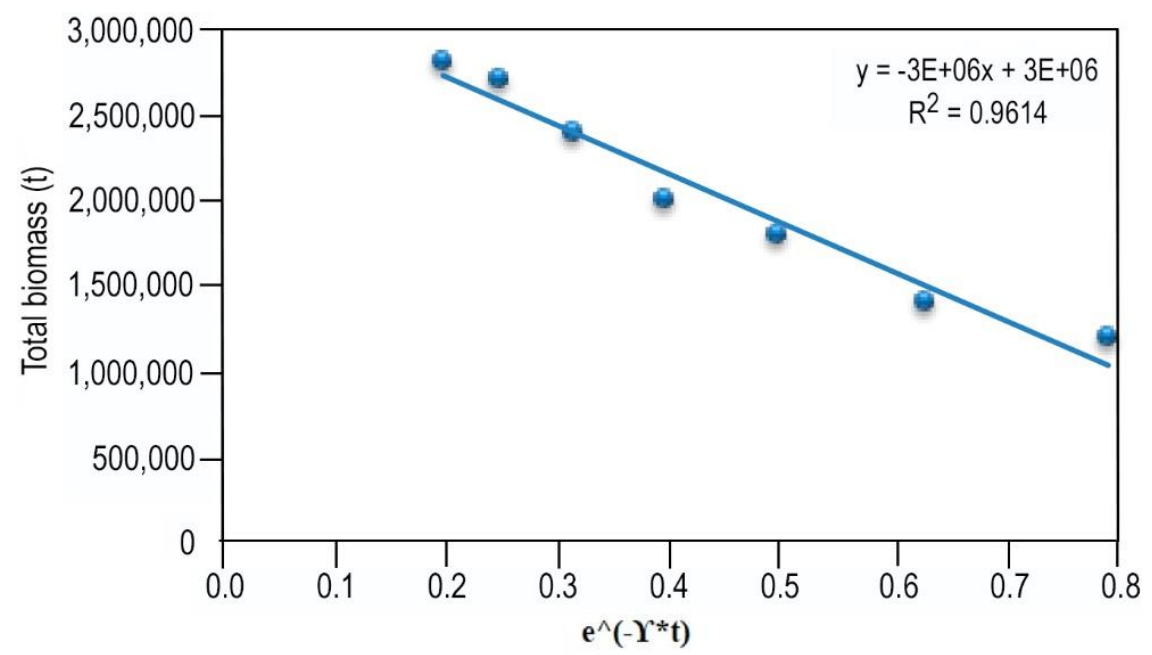

Figure 2. Carrying capacity estimation for the central-southern anchovy (Engraulis ringens) fishery $(\mathrm{K}=3,000,000)$.

pose the condition of carrying capacity on Equation 1, thus providing us with Equation 2:

$$
\frac{d B_{0}}{d t}=r\left(B_{\max }-B_{0}\right)
$$

were $B_{\max }$ is the fish carrying capacity $K$ in the region, and $B_{0}$ is the initial fish biomass. Thus, the population grows at a per-capita rate that decreases as $B_{0}$ approaches $B_{\max }$, and when $B_{0}$ is equal to $B_{\max }$, the individuals reach a net balance equal to zero, and the population establishes itself at size $B_{\max }$. To solve this model, we integrate this into Equation 2 and obtain Equation 3:

$$
\mathrm{B}_{0}(\mathrm{t})=K-\mathrm{ce}^{-r \mathrm{t}}
$$

With $c$ constant, Equation 3 allows calculating the value of $B_{\max }$ using a regression lag between the population growth rate and the biomass when time extends to infinity $t \rightarrow \infty$ (Fig. 2). We find that when the population growth is zero, the carrying capacity is $3,000,000 \mathrm{t}$.

With the fishery's estimated carrying capacity ( $\mathrm{K}=$ $3,000,000)$, it is possible to calculate the population's intrinsic growth rate, $r$, using a logistical model. Equation 4 shows the equilibrium between the population's growth and yield, where only the production surplus is caught.

$$
r B_{0}\left(1-\frac{B_{0}}{K}\right)=q E B_{0}=Y=0
$$

From Equation 4, it is possible to solve and estimate the population's intrinsic growth rate (Equation 5). The population growth estimation is presented in Table 2. At equilibrium, $d B / d t=0$ then, solving for $r$, we obtain:

$$
r=\frac{q E K}{\left(K-B_{0}\right)}
$$

where $\mathrm{r}$ : intrinsic growth rate, $q$ : catchability coefficient, $E$ : fishing effort, measured by the number of trips, $K$ : carrying capacity, and $B_{0}$ : initial biomass.

We also estimate the coefficient of industrial catchability with information available between 2011 and 2012, the period in which the collapse of the anchovy fishery began in the central-southern zone (Table 3).

\section{The bioeconomic model}

For the bioeconomic model that we propose, the fish population is distributed in two distinct ecosystems. Each one of them is characterized by its dynamics and by the union between the two zones. The area we studied is the five nautical miles reserved for artisanal fishing divided into two patches. The first patch $\left(B_{1}\right)$ is a reserve or protected area, a space where industrial and artisanal fishing is prohibited. The second patch $\left(B_{2}\right)$ is a space open to artisanal and industrial fishing. The industrial fleet only operates with constant effort and outside the first five miles offshore, with a low probability of captures, because the resource is distributed within five miles. Our model includes a biomass distribution mechanism "sink-source" in which the fish flow from the coast to the open ocean unidirectionally, with the coast acting as a nursery. It has been documented that anchovy has a unilateral migration pattern developed due to oceanographic processes like marine currents, winds, and temperatures (Yáñez et al. 1995, Parada et al. 2013).

To better understand this model, Figure 3 shows the dynamic between the different areas. The stock dynamic of the fish for each patch is:

$$
\frac{d B_{1}}{d t}=r \propto\left(B_{1}+B_{2}\right)\left(1-\frac{B_{1}+B_{2}}{K}\right)-T
$$


Table 2. Population growth rate and catchability coefficient in the central-southern anchovy (Engraulis ringens) fishery (artisanal fleet). Source: Chilean Subsecretary of Fishing and SERNAPESCA technical reports on biomass, yield, and effort for the anchovy unit of the fishery in Valparaiso to Valdivia (SUBPESCA 2018, SERNAPESCA 2019).

\begin{tabular}{ccrrccc}
\hline Year & $\begin{array}{c}\text { Total biomass } \\
(\mathrm{t})\end{array}$ & $\begin{array}{c}\text { CPUE } \\
\left(\mathrm{t} \text { trip }^{-1}\right)\end{array}$ & $\begin{array}{c}\text { Capture } \\
(\mathrm{t})\end{array}$ & $\begin{array}{c}\text { Effort } \\
(\text { trip })\end{array}$ & $\begin{array}{c}\text { Capture coefficient } \\
(q)\end{array}$ & $\begin{array}{c}\text { Growth rate } \\
(r)\end{array}$ \\
\hline 2000 & $1,200,000$ & 8.7 & 93,400 & 10,708 & $7.27 \mathrm{E}-06$ & 0.13 \\
2001 & $1,400,000$ & 16.0 & 205,800 & 12,848 & $1.14 \mathrm{E}-05$ & 0.28 \\
2002 & $1,800,000$ & 13.2 & 212,600 & 16,069 & $7.35 \mathrm{E}-06$ & 0.30 \\
2003 & $2,000,000$ & 11.6 & 201,765 & 17,337 & $5.82 \mathrm{E}-06$ & 0.30 \\
2004 & $2,400,000$ & 4.9 & 77,120 & 15,623 & $2.06 \mathrm{E}-06$ & 0.16 \\
2005 & $2,700,000$ & 12.1 & 226,690 & 18,811 & $4.46 \mathrm{E}-06$ & \\
2006 & $2,800,000$ & 31.8 & 386,052 & 12,125 & $1.14 \mathrm{E}-05$ & \\
2007 & $2,400,000$ & 12.7 & 206,770 & 16,287 & $5.29 \mathrm{E}-06$ & \\
2008 & $1,800,000$ & 14.2 & 266,319 & 18,733 & $7.90 \mathrm{E}-06$ & \\
2009 & $1,000,000$ & 9.4 & 132,436 & 14,048 & $9.43 \mathrm{E}-06$ & \\
2010 & 158,200 & 5.6 & 89,638 & 16,148 & $3.51 \mathrm{E}-05$ & \\
2011 & 124,500 & 4.2 & 61,226 & 14,556 & $3.38 \mathrm{E}-05$ & \\
2012 & 135,500 & 2.6 & 37,399 & 14,229 & $1.94 \mathrm{E}-05$ & \\
\hline Average & $1,532,169$ & 11 & 169,017 & 15,194 & $1.24 \mathrm{E}-05$ & 0.23 \\
\hline
\end{tabular}

Table 3. Estimates of the catchability coefficient in the anchovy (Engraulis ringens) fishery in the central-southern zone (industrial fleet). Source: biomass, yield, and effort for the anchovy unit of fisheries in Valparaiso to Valdivia. Subsecretary of Fishing, Chile, and technical reports from SERNAPESCA 2019.

\begin{tabular}{cccccc}
\hline Year & $\begin{array}{c}\text { Total biomass } \\
(\mathrm{t})\end{array}$ & $\begin{array}{c}\text { CPUE } \\
\left(\mathrm{t} \mathrm{trip} \mathrm{p}^{-1}\right)\end{array}$ & $\begin{array}{c}\text { Capture } \\
(\mathrm{c})(\mathrm{t})\end{array}$ & $\begin{array}{c}\text { Effort } \\
(\text { trip })\end{array}$ & Capture coefficient $(q)$ \\
\hline 2011 & 124,500 & 45.7 & 13,658 & 299 & $3.669 \mathrm{E}-04$ \\
2012 & 135,500 & 34.8 & 13,287 & 382 & $2.567 \mathrm{E}-04$ \\
\hline Average & $1,532,169$ & 11 & 169,017 & 15,194 & $1.24 \mathrm{E}-05$ \\
\hline
\end{tabular}

$$
\begin{gathered}
\frac{d B_{2}}{d t}=r(1-\propto)\left(B_{1}+B_{2}\right)\left(1-\frac{B_{1}+B_{2}}{K}\right)+T-q_{A} E_{A} B_{2}- \\
q_{I} E_{I} B_{2} \\
T=b\left(\frac{B_{1}}{K}\right)
\end{gathered}
$$

$B_{i}$ : fish biomass in patch $i$, where $i=1,2$ ( 1 is the reserve and 2 is the fishing zone), $\propto$ : level of protection of the parental stock represented by the percentage of the area that is protected, $r$ : intrinsic growth rate of the biomass of the fish stock, assumed to be equal in both zones because the same environmental conditions are present. $K$ : carrying capacity of the fish in the entire region being studied, $T$ : net transfer of biomass from the reserve to the fishing area (of $\mathrm{B}_{1}$ to $\mathrm{B}_{2}$ ), $q_{j}$ : catchability coefficient, $j=A=$ artisanal, and $j=I=$ industrial, $E_{\mathrm{j}}$ : fishing effort measured by the number of trips, where $j=A=$ artisanal and $j=I=$ industrial.

The system's results from Equations 6 and 7 correspond to a static balance where both populations experience a growth equal to zero (stationary status). Equation 8 represents the net transfer of fish biomass (T) from the marine reserve to the artisanal fishing area (from $B_{1}$ to $B_{2}$ ), where the transfer is proportional to the relative size of the protected fish biomass until it reaches the carrying capacity. We use the pre-reserve bioeconomic equilibrium equation described by Sanchirico \& Wilen (2001) to estimate this proportionality (parameter $b$ of Eq. 8). This model assumes that the fish population's intrinsic growth rate is equal in both areas because there are no differences in the ecosystem, and there is no bibliographic information related to estimating the population's growth rate (r) of the population. The bioeconomic model posits that artisanal fishers enter the system as if they had free access, incentive by the benefits until the net income dissipates, as reported by Gordon (1954) and Smith (1968).

Under the free access assumption in the fishery, it is possible to apply Equations 9, for effort (E) and 10, for yield (Y), from Sanchirico \& Wilen (2001), since the fishing effort of anchovies increased steadily over time as if it were free to access (pre-reserve).

$$
E_{j}=\frac{r}{q}\left(1-w_{j}\right)-\frac{b}{q}
$$




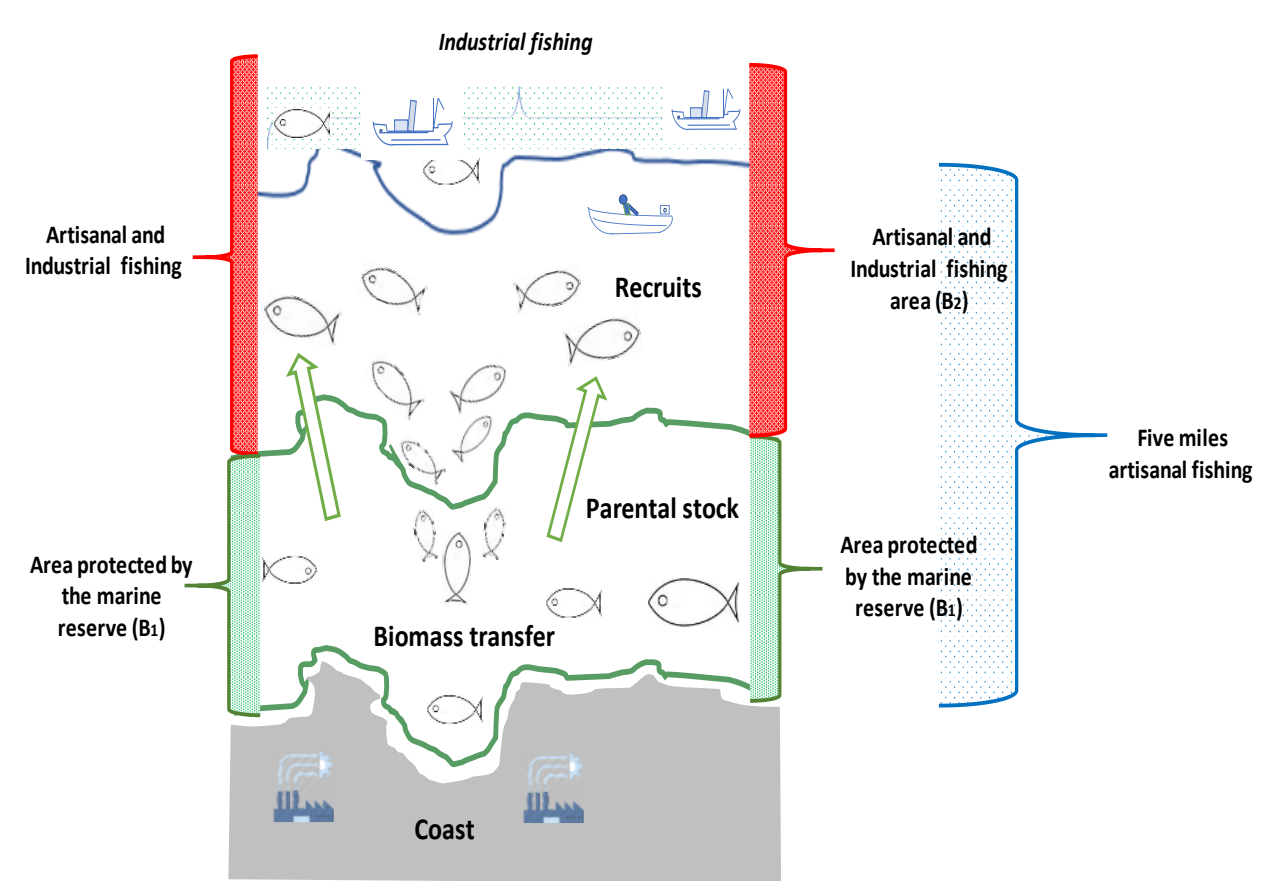

Figure 3. Schematic representation of the model.

$$
Y_{j}=r * w_{j}\left(1-w_{j}\right)-b w_{j}
$$

where $\mathrm{r}$ : intrinsic growth rate of the fish stock's biomass, $\mathrm{E}_{\mathrm{j}}$ : annual effort measured by the number of trips, $\mathrm{w}_{\mathrm{j}}$ : biomass density $\left(B_{1} / K\right)$ for year $j, \mathrm{Y}_{\mathrm{j}}$ : yield for year $j$ in $t, \mathrm{~b}$ : biomass transfer coefficient, $\mathrm{q}$ : catchability coefficient for the fishery,

Solving Equations 9 and 10, we obtain a value for the biomass density $\left(w_{j}\right)$ :

$$
w_{j}=\frac{Y_{j}}{E_{j} * q}
$$

It is possible to solve for the biomass transfer coefficient (b) by replacing (11) in (9). Table 4 shows the biomass transfer coefficient estimations in the central-southern zone fishery, using a yield coefficient of 1.177E-05 between 2000 and 2005 .

$$
b=r *\left(1-\frac{Y_{j}}{E_{j} * q}\right)-E_{j} * q
$$

Biomass movement is represented by Equations 6 and 7 , where equilibrium is achieved when $d B_{i} / d t=0$, we solve for equilibrium biomass. For both cases, $B_{e 1}$ and $B_{e 2}$, where $e$ represents equilibrium in each patch. It is then possible to obtain the following equations:

$$
\begin{aligned}
& 0=\propto K-\frac{\alpha}{r} b-q_{I} E_{I} \frac{K}{r} \\
& 0=\propto K-\frac{\alpha}{r} b-q_{A} E_{A} \frac{K}{r}
\end{aligned}
$$

With equilibrium biomass (Equations 13 and 14), it is possible to estimate the production surplus, $G(B)$, in function with artisanal effort while maintaining a constant industrial effort, represented in Equation 15:

$$
G(B)=r B_{e 1}\left(1-\frac{B_{e 1}}{K}\right)+r B_{e 2}\left(1-\frac{B_{e 2}}{K}\right)
$$

where $G(B)$ : production surplus, r: intrinsic growth rate of the biomass of the fish stock, $K$ : carrying capacity of the fish in the entire region being studied, $B_{e i}$ : biomass in equilibrium, $i=1,2$ ( 1 is reserve and 2 is the fishing zone).

The true economic value is thought to be the net benefit of processing obtained in the fishmeal industry. Because of that, our model establishes that the net benefit derived from the fishing activity is a function of the total sustainable income and the total costs:

$$
\pi=\left(P_{H}-C_{P}\right) \varphi B_{e 2}-C_{A} q_{A} E_{A} B_{e 2}-E_{I} C_{I}
$$

were $\pi$ : benefit of fishmeal production from the fishery, $P_{H}$ : price per ton of fishmeal, $C_{P}$ : cost of manufacturing, i.e. cost per ton of fishmeal produced, $B_{e 2}$ : production surplus of the fishing area $\varphi$ : efficiency factor in the production of fishmeal (tons of fishmeal per ton of yield, with an approximate value of $21 \%$ for anchovy), $C_{A}$ : cost per ton of yield obtained by the artisanal fleet, $E_{A}$ : effort of artisanal fishing, $C_{I}$ : cost per unit of applied industrial effort, $E_{I}$ : industrial effort (total trips, with or without fishing). 
Table 4. Biomass transfer coefficient in the central-southern fishery (anchovy (Engraulis ringens)). Source: biomass, yield, and effort for the anchovy unit of fisheries in Valparaiso to Valdivia. Subsecretary of Fishing, Chile (SUBPESCA 2018), and technical reports from SERNAPESCA 2019. T: net transfer of biomass from the reserve to the fishing area.

\begin{tabular}{ccrcrrrr}
\hline Year & $\begin{array}{c}\text { Total biomass } \\
(\mathrm{t})\end{array}$ & $\begin{array}{c}\text { Effort } \\
(\text { trip})\end{array}$ & $\begin{array}{c}\text { Capture coefficient } \\
(q)\end{array}$ & $\begin{array}{c}\text { Capture } \\
(\mathrm{c})(\mathrm{t})\end{array}$ & \multicolumn{1}{c}{$b$} & Bi/Bmax & \multicolumn{1}{c}{$T$} \\
\hline 2000 & $1,200,000$ & 10,708 & $1.177 \mathrm{E}-05$ & 93,400 & 172,489 & 0.40 & 68,996 \\
2001 & $1,400,000$ & 12,848 & $1.177 \mathrm{E}-05$ & 205,800 & 316,762 & 0.47 & 147,822 \\
2002 & $1,800,000$ & 16,069 & $1.177 \mathrm{E}-05$ & 212,600 & 261,636 & 0.60 & 156,982 \\
2003 & $2,000,000$ & 17,337 & $1.177 \mathrm{E}-05$ & 201,765 & 230,142 & 0.67 & 153,428 \\
2004 & $2,400,000$ & 15,623 & $1.177 \mathrm{E}-05$ & 77,120 & 97,617 & 0.80 & 78,094 \\
2005 & $2,700,000$ & 18,811 & $1.177 \mathrm{E}-05$ & 226,690 & 238,311 & 0.90 & 214,480 \\
\hline
\end{tabular}

\section{Economic parameters considered in the benefits estimation}

We use USD $1490 \mathrm{t}^{-1}$ as the price of fishmeal $\left(P_{H}\right)$. For the manufacturing process $\operatorname{cost}\left(C_{P}\right)$, we use an average value of USD $250 \mathrm{t}^{-1}$ (Jaramillo 2016). The cost per unit of effort in artisanal fishing $\left(C_{A}\right)$ is USD $391 \mathrm{t}^{-1}$, and the cost per unit of effort or cost of a trip of one unit of the industrial fleet $\left(C_{A}\right)$ is USD 23,280 trip $^{-1}$. Prices and costs have been obtained from Cerda et al. (2014).

\section{RESULTS}

It is important to remember that the results we present here assume a condition of equilibrium of a stationary state or zero biomass growth. Thus, all results are gathered from static comparisons: unions of equilibrium conditions that account for the movements from one equilibrium to another. To simulate the model, we used fishing efforts between 0 and 20,000 trips (within the range of the levels observed in Chile at the time) and different sizes of potential marine reserves, between 0 and $60 \%$ of the total area. Also, the model incorporates the spatial distribution component of fish biomass and that of fishers, considering the homogeneous distribution of the resource. It allows relating the percentage of area protected with biomass. These assumptions simplify the problem's complexity and allow reasonable results to be found (e.g. Sanchirico \& Wilen 2001, Cartigny et al. 2008).

Furthermore, our model uses the initial biomass from 2006, given that this was the record maximum. For the intrinsic growth rate $(r)$ parameters, we use the average value of 0.23 , considering the average value of both fleets' catchability coefficient $\left(q_{i}\right)$. The industrial effort remains constant, and the artisanal effort is variable because of the bioeconomic model's characteristics, unlike the artisanal fleet, whose number of vessels has increased until 2012 (SUBPESCA 2018, SERNAPESCA 2019). The industrial fleet has not undergone major changes for several years. For this reason, it has been assumed that the effort of the artisanal fleet is variable, and the industrial is constant. While the artisanal fleet can capture recruits by operating within 5 miles, the industrial fleet operates outside of the 5 miles where fish biomass is not significant relative to the artisanal area. We obtained the following parameters and initial values of the state variables, where $B_{0}=B_{1}+B_{2}$ (Table 5).

\section{Fishery biomass equilibrium}

As artisanal fishing effort increases with a marine reserve, the fishery's biomass equilibrium tends to be lower for all levels of reserve size (Fig. 4). If the reserve percentage or size increases from 0 to $60 \%$, more biomass will be protected from increases in effort. Because of that, the reserve's protection has a negative effect on artisanal yield. Furthermore, a reserve's existence ensures that a certain portion of the parental fish stock will be protected. In this case, with a $30 \%$ level of reserve, which is considered optimal, it would have been possible to maintain biomass equilibrium in order to $1,000,000 \mathrm{t}$ at 20,000 trips, the maximum level of effort in this simulation (Fig. 4).

\section{Biomass in the reserve or protected area}

If a marine reserve area were created to manage the anchovy fishery in the central-southern zone, the levels of equilibrium biomass in reserve would increase, facilitating a greater fishing effort. That said, in situations where the reserve is smaller than $30 \%$, the protected biomass equilibrium would fall as the artisanal fishing effort grew. Above 30\%, the protected biomass increases, and at 30\%, it remains relatively constant, which implies that the optimal level of protection is $30 \%$ to maintain protected biomass since it allows that the artisanal fishery continues in profitable form (Fig. 5).

\section{Biomass in the fishing area}

Biomass equilibrium in the fishing area can be divided into two different situations: first, without protection, 
Table 5. Values of the state variables and model parameters.

\begin{tabular}{lc}
\hline $\begin{array}{l}\text { Endogenous } \\
\text { variables }\end{array}$ & Initial value \\
\hline$B_{0}(t)$ & $2,800,000$ \\
$B_{I}$ & $\alpha \mathrm{B}_{0}$ \\
$B_{2}$ & $(1-\alpha) \mathrm{B}_{0}$ \\
\hline Parameters & Values \\
\hline$r$ & 0.23 \\
$K(t)$ & $3,000,000$ \\
$b$ & 220,204 \\
$q_{A}$ & $1.17 \mathrm{E}-05$ \\
$E_{I}$ & 340 \\
$q_{I}$ & $3.11 \mathrm{E}-04$ \\
\hline
\end{tabular}

the fishing area's biomass is zero in levels equal to or higher than 14,000 trips (blue line in Fig. 6). Second, for about 14,000 units of effort, the importance of protection becomes apparent because, with any size reserve, there is biomass equilibrium available for fishing, an amount that decreases as the amount of effort increases. It is possible to observe that for protections of $30,40,50$, and $60 \%$, the levels of biomass equilibrium in the fishing area are similar, and these levels decrease with higher levels of effort. That is, $30 \%$ of protection is enough to allow the fleet to continue harvesting (Fig. 6). In the case of a fishery without protection (reserve of $0 \%$ ) with 18,000 units of effort, a level equivalent to the number of trips taken in 2017 in the central-southern zone of Chile (SUBPESCA, 2018), biomass equilibrium collapses in the fishing area without any possibility for maintaining parental stock to support this level of fishing effort (Fig. 6). Again, an adequate measure would have been to protect $30 \%$ of the area, guaranteeing parental stock and maintaining production surplus levels over time (Fig. 6).

\section{Production surpluses}

In conditions of equilibrium, sustainable yields are equal to production surpluses, which, theoretically, should be equal to the global catch quota determined by the authorities, which is feasible since marine reserves allow to have a protected parental stock, which guarantees this proposal.

Increasing the reserve size would have two main effects: on the one hand, it would restrict the area available for artisanal fishing. On the other hand, it would increase the production surplus available because of fish migration's effects towards the fishing area. When the fishing effort grows, the yield then depends exclusively on the transfer of fish biomass. More protection generates a higher production surplus or a growing surplus level that is not caught because these surpluses grow with the area's size in the marine reserve. According to Boncoeur et al. (2002), the economic benefits desired by the fishery would be guaranteed with $30 \%$ protection. If this principle of marine reserves were applied for fishery management, with 18,000 units of effort and 30\% protection, the anchovy fishery in the central-southern zone of Chile could have an annual yield in the order of 200,000 t (Fig. 7).

\section{Bioeconomic equilibrium: fishery income and costs}

The incomes and costs of artisanal and industrial fishing, according to the fishing effort (variable artisanal and fixed industrial), for different levels of marine reserve (\% of protection), indicate that without protection ( $0 \%$ reserve), the incomes are always higher than the costs (green lines in Fig. 8). It might have incentivized the increasing number of fishing vessels that led to the anchovy fishery collapse in Chile's central-southern zone. In Figure 8, it is also possible to observe that, hypothetically, with levels of protection above $30 \%$, it would be possible to achieve bioeconomic equilibrium (a level of effort where the total costs are equal to the total incomes) approximately 13,000 units of effort. Given the conditions of effort used in 2017 by 18,000 trips with a $0 \%$ level of protection and has established the relationship between the benefits and the cost of the fishery in a condition of equilibrium, we can confirm that bioeconomic equilibrium was not achieved in the Chilean anchovy fishery and the fishing effort increased.

\section{DISCUSSION}

This study has extrapolated the state of bioeconomic variables in the Chilean anchovy fishery's centralsouthern zone, evaluating other marine reserves' size effect. The simplicity of the bioeconomic model we use gives us a closer view of what happened during the period under study (2000-2012), highlighting how the artisanal fishing effort grew to surpass the bioeconomic equilibrium of 13,000 units of effort.

This study responds to the question posed by the United Nations Convention on the Law of the Sea insists that researchers and policymakers must determine what kinds of holistic policies can be implemented to manage fisheries to protect and sustain biodiversity. Using marine reserves and modifying fishing techniques are conservation measures that most experts agree upon (Worm et al. 2009, Hilborn \& Ovando 2014, Costello \& Ballantine 2015, Hilborn 2016, Jupiter et al. 2017, Chapsos et al. 2019).

Due to a global quota distributed among vessels which were increased every year since its initial proposal, especially in Chile's central-south zone (SUBPESCA 2018), and due to the high price of fishmeal during the researched years, there was a higher 


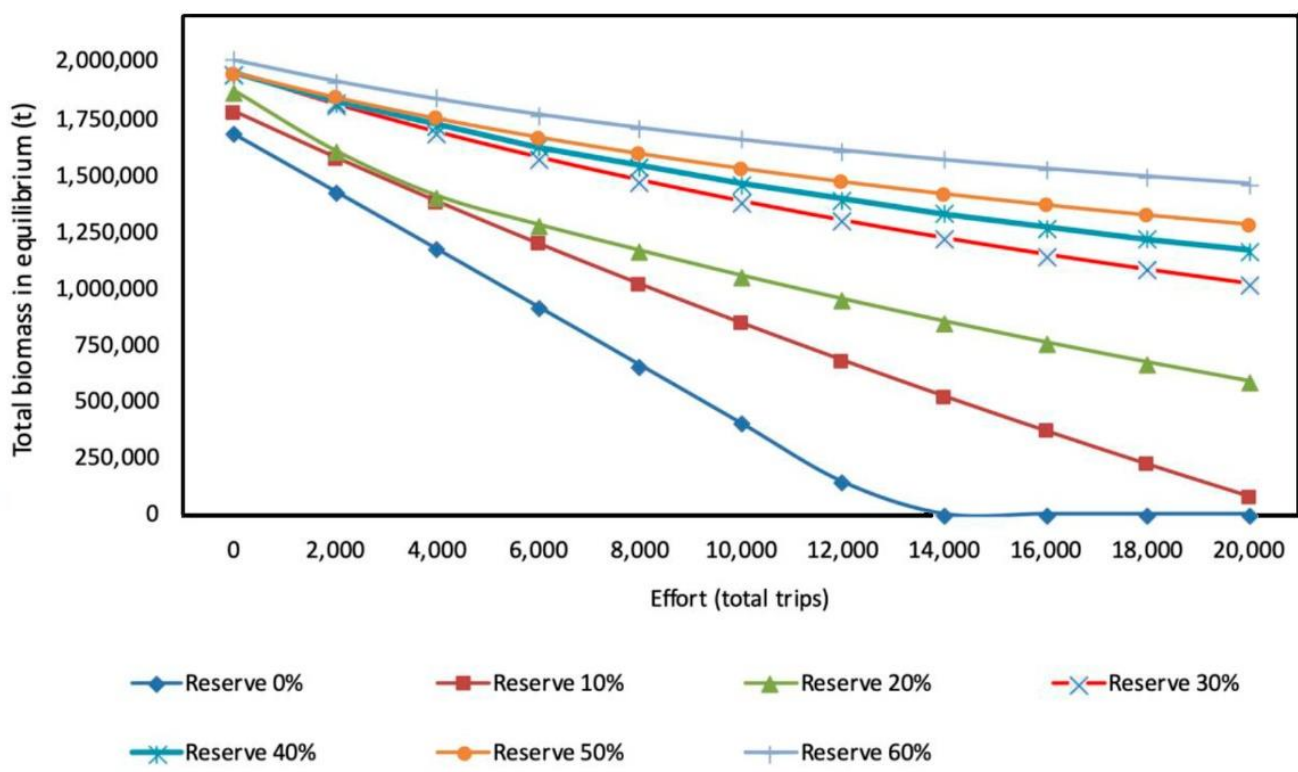

Figure 4. Effect on total biomass ( $\mathrm{t}$ ) of different levels of effort (total trips) with varying levels of the marine reserve area.
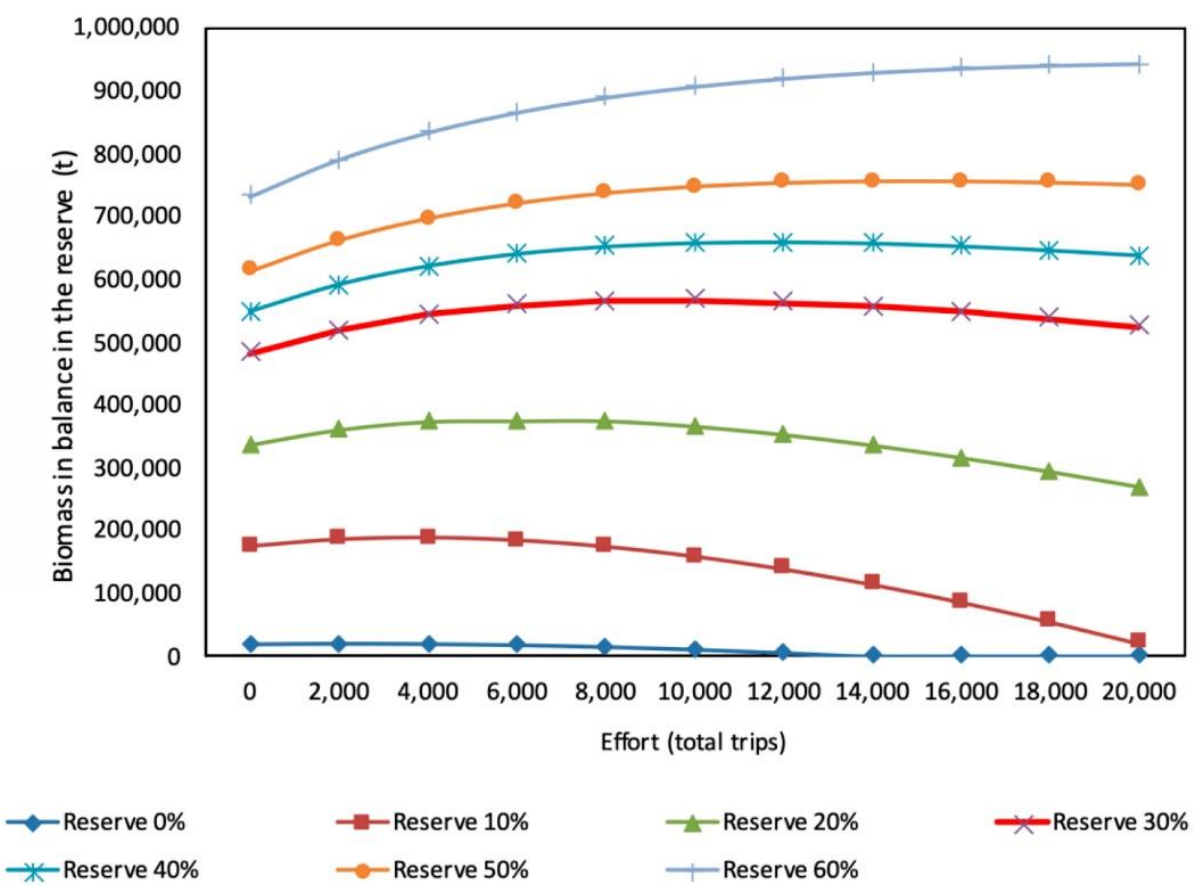

$-1-$ Reserve $20 \%$
- Reserve $60 \%$

$\longrightarrow$ Reserve $30 \%$

Figure 5. Evolution of biomass (t) balance in the reserve in function with fishing effort (total trips) for different levels of the marine reserve area.

incentive to increase levels of fishing effort. Exceeding the initial quotas revealed a non-precautionary approach to managing the fishery, which led to the anchovy fishery's inevitable collapse. In a sense, the fishery operated as if it were open access. It was encouraged by the "olympic race" phenomenon (Conrad \& Clark 1987, Clark 1996, Anderson 2000), inevitably leading to overinvestment in more efficient fishing supplies so that harvesters were better able to compete for access to this resource. A result that Hardin (1968) predicted for a society that believes in freedom of the commons: "ruin is the destination toward which all men rush, each pursuing his own best interest ..." (Hardin, 1968).

Our model results reveal the important role that protecting part of the resource plays in the fishery's stability. They emphasize the importance of using mari- 


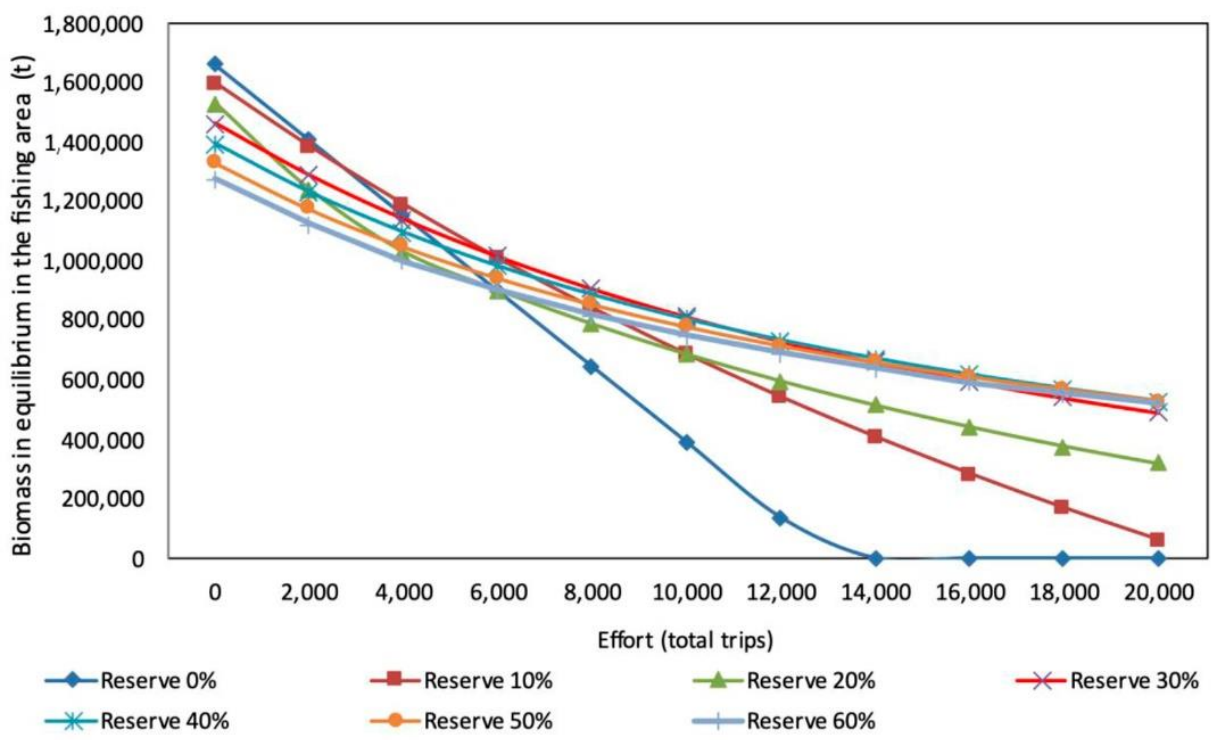

Figure 6. Evolution of biomass (t) balance in the fishing area as a function of effort (total trips) at different marine reserve areas.

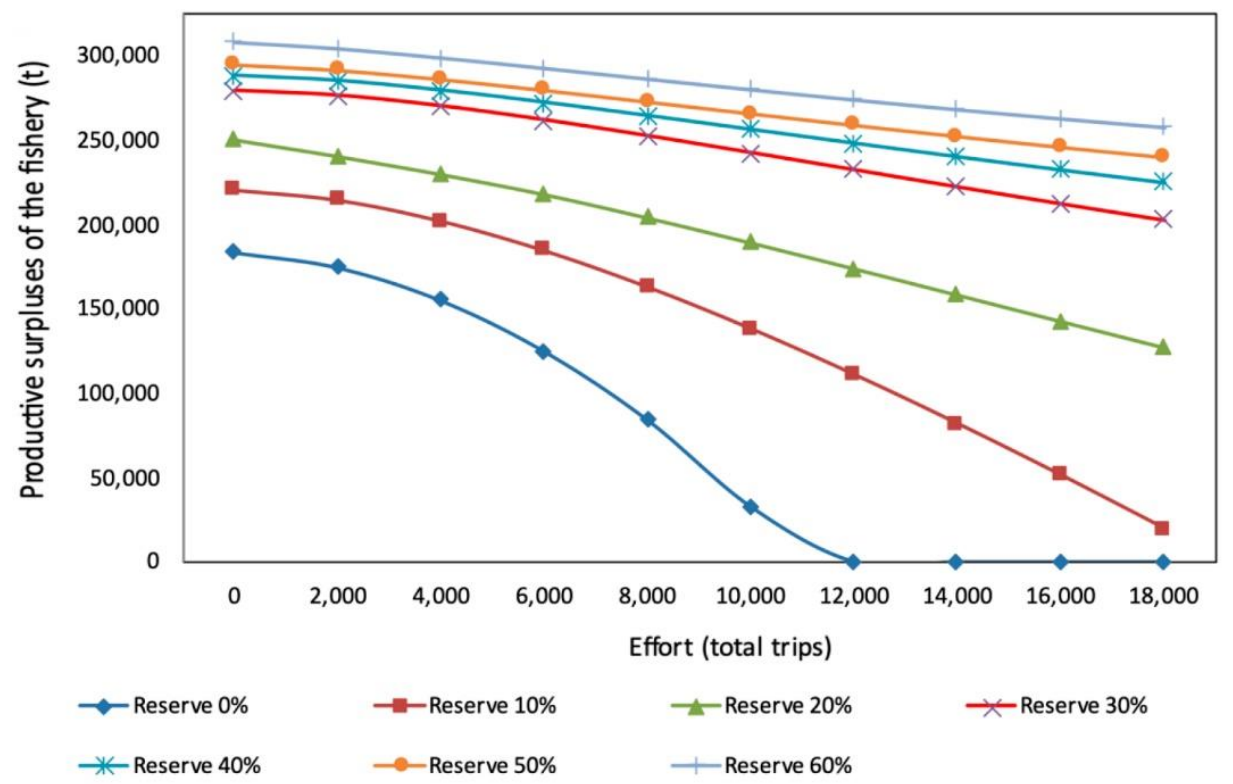

Figure 7. Evolution of the fishery's production surplus in function with an effort at different levels of protection.

ne reserves as a management policy to protect a percentage of the parental stock because it indirectly regulates effort and obligates harvesters to operate close to the bioeconomic equilibrium. From a management perspective, marine reserves are an efficient tool. However, it is necessary to study and incorporate the climate change effect into the model, especially on the spatial distribution of the resource and the population's specific growth rate. More importantly, is the effect of climate variability due to its impact on fish stock (abundance and biomass) and fishery management instruments over time.

Future studies must consider in situ measures for migration or displacement of anchovy from the protected area to the fishing grounds to improve the model's reliability. That said, this study, which considers the theoretic model of transfer proposed by Sanchirico \& Wilen (2001), presents a simulation that can be used for decision making. As Boncoeur et al. (2002) have indicated, static modeling of the problem 


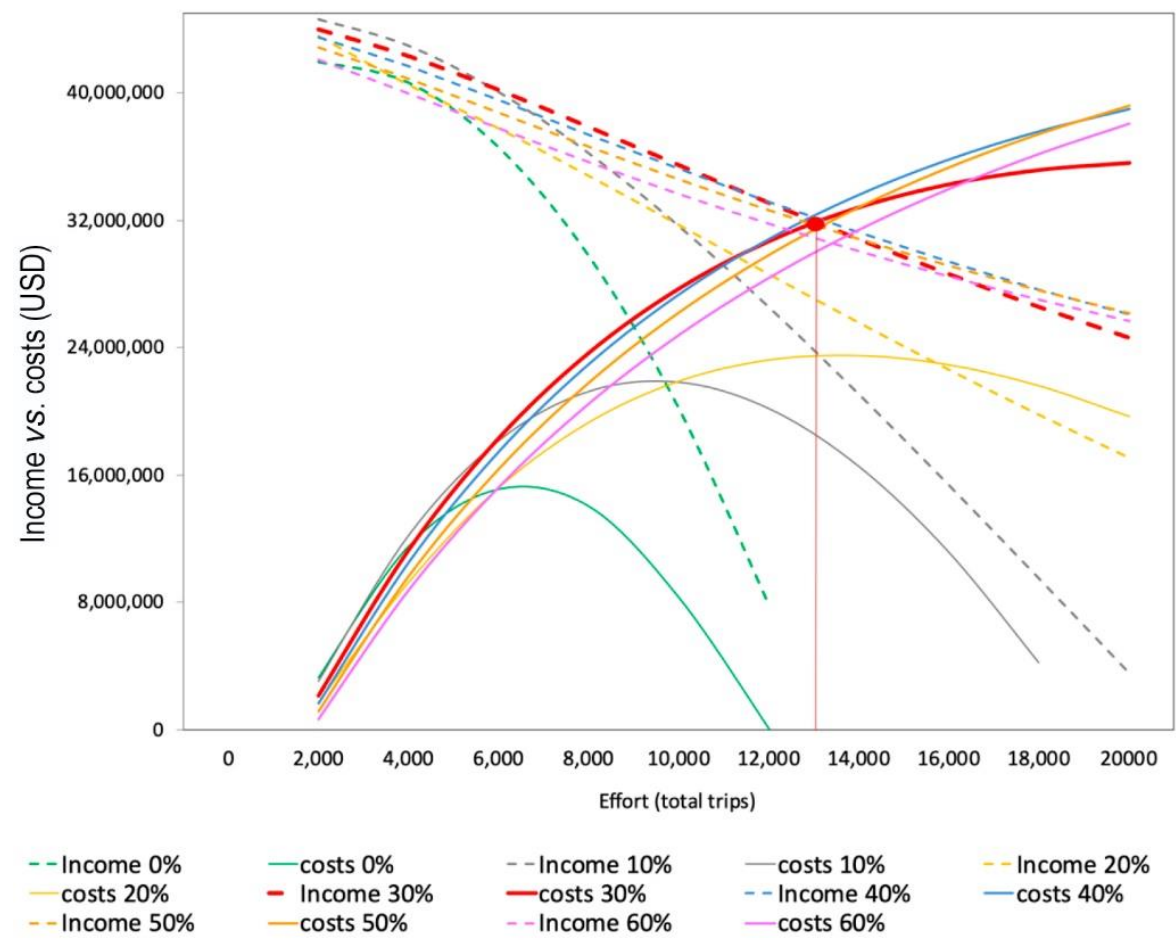

Figure 8. Fishery income $v s$.cost relationship in function with an effort (total trips) at different levels of protection.

allows us to evaluate the fishing effort, biomass, and benefits for different levels of fishery protection, giving us more information that we would be able to get empirically, findings confirmed by like Bohnsack (1996), Parrish (1999), Jennings (2000), Li (2000), Mangel (2000) and Cartigny et al. (2008).

Reserves reduce uncertainty in the valuation of biodiversity and the stock's economic value and, thus, allow us to control the effort, which guarantees the sustainability of the fishery and improves the quality of management. These findings are in line with, Guénette et al. (1998), Lauck et al. (1998) and Boncoeur et al. (2002). The success of these reserves is possible, provided that a bioeconomic model can be designed for the fishery that allows management to calculate the trade-off between conservation and the pressure of an increasing fishing effort (Cabral et al. 2019).

One critical aspect of modeling is determining the fish's intrinsic population growth rate $\left(\gamma_{f}\right)$ and the biomass transfer coefficient (b) from the reserve area to the fishing grounds since the model results depend on these parameters. So long as these parameters are wellestimated, the model presented here offers many advantages because it uses easy-to-access public statistical data and generates reliable results consistent with bioeconomic research on fisheries. The fish (b) at levels of protection over $30 \%$ has a negative impact on production surplus because harvesters have less possibility of catching the protected surplus. As the number of fishing vessels (effort) grows, the biomass transfer from the protected zone to the fishing area becomes more important because the yield depends mainly on this transfer and protection level. The 30\% protection level is consistent with that reported by Krueck et al. (2017), who carried out a theoretical analysis on marine reserves' ability to rebuild overexploited fisheries. They assert that reserve networks can realistically protect between $10 \pm 30 \%$ of the fish habitats in reserves of $1 \pm 20 \mathrm{~km}$ wide, which would benefit almost any fishery's long-term productivity. In this modeling, the artisanal fleet's effort is considered variable as it has exclusivity within 5 miles, and a considerable increase of this fleet is observed in the study period. Given this, it is difficult for the industrial fleet to grow as its capture is subject to the artisanal fleet's movements. Given the unlikely situation that the industrial fleet will increase, it would only generate overinvestment, and it would self-regulate since the anchovy is a coastal pelagic resource, concentrating mainly within 5 miles.

This study outlines the economic advantages of using marine reserves as a tool for fishery management. Holland \& Brazee (1996) demonstrated that even the fisheries that have been most damaged by overex- 
ploitation could be rebuilt by implementing protected areas of marine reserves. Halpern et al. (2009) and Pérez-Ruzafa et al. (2017) have confirmed the ample ecological advantages of reserves. Finally, McGowan \& Possingham (2015) and Starr et al. (2015) have indicated that the benefits of reserves range from an increased richness in species (biodiversity) to larger fish biomass and more complex habitat, both inside and outside of the reserve. Furthermore, these two last authors indicate that marine reserves provide important financial gain through tourism-related income, and they provide greater opportunities for community education and recreational activities.

According to Boncoeur et al. (2002) and PérezRuzafa et al. (2017), the potential biological benefits of establishing a marine reserve are that reserves: 1) preserve the regional biological diversity at all levels, including habitats and marine landscapes, as well as genetic diversity, allowing for natural selection to function adequately; 2) protect biomass during their spawning periods; 3 ) maintain a source of recruitment in areas surrounding fishing grounds; 4) replace supplemental stock in fishing areas through immigration; 5) maintain the age structure of the natural population in the reserve area, thus maximizing potential fertility and facilitating biomass transfer to occur from the nucleus of regulated areas; 6) maintain areas with calm, noise-free habitats, which alleviates stress on the fish; 7) allow for natural variability in order to differentiate the effects of regulation and provide appropriate sample situations for control groups; and 8) protect fisheries from potential management failures.

It is essential to change from a traditional paradigm to a more integral, holistic approach to fishery management by focusing on ecosystems. A good example of this is currently playing out in Indonesia, where ecosystems are considered fishery management's focus. It is the best and most practical approach to the fisheries' long-term sustainability and the eco-systemic services they provide society (Muawanah et al. 2018).

\section{CONCLUSIONS}

According to the model presented in this paper and the results we obtained through it, the anchovy fishery's collapse in Chile's central-southern zone between 2013 and 2018 could have been avoided. Designating a percentage of a fishing area for a marine reserve guarantees sustainable yields for artisanal fishers. The optimal level of protection is $30 \%$ of the fishing area, allowing the fishery to be managed at high levels of effort, including the 18,000 trips registered in 2017.
This level of protection guarantees yields for the artisanal harvesters who must coexist with the industrial fleet. We have demonstrated that the bioeconomic model presented here can be a useful tool that helps guarantee fisheries' sustainability. The proposed solution is viable so long as there is a legal and regulatory framework that includes the marine reserve area as a fishery management policy and that includes the considerations of artisanal fishing communities.

\section{REFERENCES}

Anderson, L.G. 2000. The effects of ITQ implementation: a dynamic approach. Natural Resource Modeling, 134: 435-470. doi: 10.1111/j.1939-7445.2000.tb00043.x

Arcos, D., Núñez, S.P., Castro, L. \& Navarro, N. 1987. Variabilidad vertical de clorofila a en un área de surgencia frente a Chile central. Investigacion Pesquera, 34: 47-55.

Arteaga, M. \& Cubillos, L. 2008. Análisis de los cambios de abundancia de sardina común (Strangomera bentincki): estructura año calendario versus año biológico. Latin American Journal of Aquatic Research, 36: 137-151. doi: 10.3856/vol36-issue2fulltext-1

Arteaga, M., Alarcón, J. \& Vargas, S. 2010. Monitoreo y estructura en las capturas de los recursos anchoveta (Engraulis ringens) y sardina común (Strangomera bentincki) en los límites regionales de la VIII Región 2010, Concepción. Instituto de Investigación Pesquera, Concepción.

Bakun, A. 1989. Recruitment in fishery resources and its relationships to environment: accessible pathways to greater insight. In: Memorias del Simposio International de los Recursos Vivos y las Pesquerías en el Pacífico Sudeste. Comisión Permanente del Pacífico Sur, pp. 9-13.

Basulto del Campo, S. 2014. Noticias pesqueras de cinco siglos - Chile: 1520-2000. Ocho Libros, Santiago.

Beverton, R.J.H. 1983. Science y decision-making in fisheries regulations. In: Sharp, G.D. \& Csirke, J. (Eds.). Proceedings of the expert consultation to examine changes in abundance and species composition of neritic fish resources. FAO Fisheries Report, 291: 919-936.

Bohnsack, J.A. 1996. Marine reserves, zoning, and the future of fishery management. Fisheries, 29: 14-16.

Boncoeur, J., Alban, F., Guyader, O. \& Thebaud, O. 2002. Fish, fishers, seals and tourists: economic consequences of creating a marine reserve in a multispecies, multi-activity context. Natural Resource Modeling, 15: 387-411. doi: 10.1111/j.1939-7445. 2002.tb00095.x

Cabral, R.B., Halpern, B.S., Lester, S.E., White, C., Gaines, S.D. \& Costello, C. 2019. Designing MPAs 
for food security in open-access fisheries. Scientific Reports, 9: 1-10. doi: 10.1038/s41598-019-44406-w

Caddy, J. \& Sharp, G.D. 1988. Un marco ecológico para la investigación pesquera. FAO Documentos Técnicos de Pesca 283:155 pp.

Cartigny, P., Gómez, W. \& Salgado, H. 2008. The spatial distribution of small- and large-scale fisheries in a marine protected area. Ecological Modelling, 212: 513-521. doi: 10.1016/j.ecolmodel.2007.11.001

Cerda, R., Ahumada, M., González-Poblete, E. \& Queirolo, D. 2014. Modelo estructura de costos de la flota pesquera nacional y plantas de proceso. Pontificia Universidad Católica de Valparaíso, Estudios y Documentos, 4728-57-LE13.

Chapsos, I., Koning, J. \& Noortmann, M. 2019. Involving local fishing communities in policymaking: addressing illegal fishing in Indonesia. Marine Policy, 109: 103708. doi: 10.1016/j.marpol.2019.103708

Clark, C.W. 1996. Marine reserves and the precautionary management of fisheries. Ecological Applications, 6: 369-370. doi: 10.2307/2269374

Conrad, J.M. \& Clark, C.W. 1987. Natural resource economics: notes and problems. Cambridge University Press, Cambridge.

Costello, M.J. \& Ballantine, B. 2015. Biodiversity conservation should focus on no-take marine reserves: $94 \%$ of marine protected areas allow fishing. Trends in Ecology and Evolution, 30: 507-509. doi: 10.1016/ j.tree.2015.06.011

Cubillos, L. \& Arancibia, H. 1993a. Análisis de la pesquería de sardina común (Strangomera bentincki) y anchoveta (Engraulis ringens) del área de Talcahuano, Chile. Investigaciones Marinas, Valparaíso, 21: 3-21.

Cubillos, L. \& Arancibia, H. 1993b. On the seasonal growth of common sardine (Strangomera bentincki) and anchovy (Engraulis ringens) off Talcahuano, Chile. Revista de Biología Marina, 28: 43-49.

Cubillos, L. \& Arcos, D. 2002. Recruitment of common sardine (Strangomera bentincki) and anchovy (Engraulis ringens) off central-south Chile in the 1990s and the impact of the 1997-1998 El Niño. Aquatic Living Resources, 15: 87-94. doi: 10.1016/ S0990-7440(02)01158-0

Cubillos, L., Arcos, D., Bucarey, D. \& Canales, M. 2001. Seasonal growth of small pelagic fish off Talcahuano, Chile $\left(37^{\circ} \mathrm{S}, 73^{\circ} \mathrm{W}\right)$ : a consequence of their reproductive strategy to seasonal upwelling? Aquatic Living Resources, 14: 115-124. doi: 10.1016/S09907440(01)01112-3

Cubillos, L., Canales, M., Hernández, R., Bucarey, S., Vilugrón, L. \& Miranda, A. 1998. Poder de pesca, esfuerzo de pesca y cambios estacionales e interanuales en la abundancia relativa de Strangomera bentincki y Engraulis ringens en el área frente a
Talcahuano, Chile (1990-97). Investigaciones Marinas, Valparaíso, 26: 3-14. doi: 10.4067/S0717-71781998 002600001

Daneri, G., Dellarossa, V., Quiñones, R., Jacob, B., Montero, P. \& Ulloa, O. 2000. Primary production and community respiration in the Humboldt Current System off Chile and associated oceanic areas. Marine Ecology Progress Series, 197: 41-49. doi: 10.3354/ meps 197041

Díaz, J.P. \& Salgado, H. 2006. Manejo de pesquerías mediante la zonificación de áreas de reserva: aplicación a la pesquería de la anchoveta (Engraulis ringens) en el norte de Chile. Investigaciones Marinas, 34: 109-124. doi: 10.4067/s0717-71782006000200 011

Gatica, C., Arteaga, M., Giacaman, J. \& Ruiz, P. 2007. Tendencias en la biomasa de sardina común (Strangomera bentincki) y anchoveta (Engraulis ringens) en la zona centro-sur de Chile, entre 1991 y 2005. Investigaciones Marinas, 35: 13-24. doi: $10.4067 / \mathrm{s} 0717-71782007000100002$

Goñi, R., Adlerstein, S., Alvarez-Berastegui, D., Forcada, A., Reñones, O., Criquet, G., et al., 2008. Spillover from six western Mediterranean marine protected areas: evidence from artisanal fisheries. Marine Ecology Progress Series, 366: 159-174. doi: 10.3354/ meps07532

Gordon, H. 1954. The economic theory of a commonproperty resource. The fishery. Journal of Political Economy, 62: 124-142.

Guénette, S., Lauck, T. \& Clark, C. 1998. Marine reserves: from Beverton and Holt to the present. Reviews in Fish Biology and Fisheries, 8: 251-272. doi: 10.1023/ A:1008859130275

Halpern, B.S., Lester, S.E. \& Kellner, J.B. 2009. Spillover from marine reserves and the replenishment of fished stocks. Environmental Conservation, 36: 268-276. doi: 10.1017/S0376892910000032

Hardin, G. 1968. The tragedy of the commons author(s). Science, 162: 1243-1248.

Harrison, H.B., Williamson, D.H., Evans, R.D., Almany, G.R., Thorrold, S.R., Russ, G.R., et al., 2012. Larval export from marine reserves and the recruitment benefit for fish and fisheries. Current Biology, 22: 1023-1028. doi: 10.1016/j.cub.2012.04.008

Hérubel, M.A. 1912. Sea fisheries: their treasures and toilers. Journal of the Royal Society of Arts, 60: 542544.

Hilborn, R. 2016. Policy: marine biodiversity needs more than protection. Nature, 535: 224-226. doi: 10.1038/ $535224 \mathrm{a}$ 
Hilborn, R. \& Ovando, D. 2014. Reflections on the success of traditional fisheries management. ICES Journal of Marine Science, 71: 1040-1046. doi: 10.1093/icesjms/fsu034

Holland, D.S. \& Brazee, R.J. 1996. Marine reserves for fisheries management. Marine Resource Economics, 11: 157-171. doi: 10.1086/mre.11.3.42629158

Instituto de Fomento Pesquero (IFOP). 2008. Investigación evaluación hidroacústica del reclutamiento de anchoveta y sardina común V y X regiones, 20062007. IFOP, Valparaíso.

Jaramillo, F.J. 2016. Evaluación de estrategias de producción aplicadas a una planta pesquera. Tesis de Magister, Universidad de Concepción, Concepción.

Jennings, S. 2000. Patterns and prediction of population recovery in marine reserves. Reviews in Fish Biology and Fisheries, 10: 209-231. doi: 10.1023/A:101661 9102955

Jupiter, S.D., Epstein, G., Ban, N.C., Mangubhai, S., Fox, M. \& Cox, M. 2017. A social-ecological systems approach to assessing conservation and fisheries outcomes in Fijian locally managed marine areas. Society and Natural Resources, 30: 1096-1111. doi: 10.1080/08941920.2017.1315654

King, J. \& McFarlane, G. 2005. Implications for the management of marine resources. In: King, J.R. (Ed.). Report of the study group on fisheries and ecosystem responses to recent regime shifts. North Pacific Marine Science Organization, Sidney, pp. 50-54.

Krueck, N.C., Ahmadia, G.N., Possingham, H.P., Riginos, C., Treml, E.A. \& Mumby, P.J. 2017. Marine reserve targets to sustain and rebuild unregulated fisheries. Plos Biology, 15: 1-20. doi: 10.1371/journal.pbio. 2000537

Lauck, T., Clark, C.W., Mangel, M. \& Munro, G.R. 1998. Implementing the precautionary principle in fisheries management through marine reserves. Ecological Applications, 8: 71-78.

Li, E. 2000. Optimum harvesting with marine reserves. North American Journal of Fisheries Management, 20: 882-896. doi: 10.1577/1548-8675(2000)020<0882: ohwmr>2.0.co;2

Mangel, M. 2000. Irreducible uncertainties, sustainable fisheries and marine reserves. Evolutionary Ecology Research, 2: 547-557.

McGowan, J. \& Possingham, H.P. 2015. Submission to the Commonwealth Marine Reserves Review. The University of Queensland, Queensland. doi: 10.13140/ RG.2.1.1585.8082

Morales, E., Gómez, V., Félix, R. \& Alvarado, R. 2003. Relation between recruitment, sea surface temperature, and the density-independent mortality of the Pacific sardine (Sardinops caeruleus) off the southwest coast of the Baja California Peninsula,
Mexico. Scientia Marina, 67: 25-32. doi: 10.3989/ scimar.2003.67n125

Muawanah, U., Yusuf, G., Adrianto, L., Kalther, J., Pomeroy, R., Abdullah, H. \& Ruchimat, T. 2018. Review of national laws and regulation in Indonesia in relation to an ecosystem approach to fisheries management. Marine Policy, 91: 150-160. doi: 10.1016/j.marpol.2018.01.027

Parada, C., Yannicelli, B., Hormazábal, S., Vásquez, S., Porobić, J., Ernst, B. \& Gretchina, A. 2013. Environmental variability and fisheries in the southeastern Pacific: research status and challenges for fisheries management. Latin American Journal of Aquatic Research, 41: 1-28.

Parrish, R. 1999. Marine reserves for fisheries management: why not. Reports of California Cooperative Oceanic Fisheries Investigations Reports, 40: 77-86.

Pedraza-Garcia, M. \& Cubillos, L. 2008. Population dynamics of two small pelagic fish in the central-south area off Chile: delayed density-dependence and biological interaction. Environmental Biology of Fishes, 82: 111-122. doi: 10.1007/s10641-007-9260-3

Pérez-Ruzafa, A., García-Charton, J. \& Marcos, C. 2017. North East Atlantic vs. Mediterranean marine protected areas as fisheries management tool. Frontiers in Marine Science, 4: 1-13. doi: 10.3389/fmars.2017. 00245

Pitcher, T.J. 1995. The impact of pelagic fish behaviour on fisheries. Scientia Marina, 59: 295-306.

Porobic, J., Fulton, E.A., Frusher, S., Parada, C., Haward, M., Ernst, B. \& Stram, D. 2018. Implementing ecosystem-based fisheries management: lessons from Chile's experience. Marine Policy, 97: 82-90. doi: 10.1016/j.marpol.2018.08.037

Roberts, C.M. \& Polunin, N. 1991. Are marine reserves effective in management of reef fisheries? Reviews in Fish Biology and Fisheries, 1: 65-91. doi: 10.1007/ BF00042662

Sanchirico, J.N. \& Wilen, J.E. 2001. A bioeconomic model of marine reserve creation. Journal of Environmental Economics and Management, 42: 257-276. doi: 10.1006/jeem.2000.1162

Sepúlveda, A., Cubillos, L. \& Arcos, D. 2003. Pesquerías pelágicas chilenas: una síntesis sobre la incertidumbre biológica. In: Yáñez, E. (Ed.). Actividad pesquera y de acuicultura en Chile. Pontificia Universidad Católica de Valparaíso, Valparaíso, pp. 91-107.

Servicio Nacional de Pesca y Acuicultura (SERNAPESCA). 2019. Anuario 2007-2019. SERNAPESCA, Valparaíso.

Serra, J.R. 1983. Changes in the abundance of pelagic resources along the Chilean coast. FAO Fisheries Report, 2: 255-284. 
Smith, V.L. 1968. Economics of production from natural resources. American Economic Review, 58: 409-431.

Soto, E. \& Paredes, C. 2018. La regulación de la pesquería a través de la historia. In: Fariña, F. (Ed.). La regulación pesquera a través de la historia: la génesis de un colapso. Fundación Terram, Santiago.

Starr, R.M., Wendt, D.E., Barnes, C.L., Marks, C.I., Malone, D., Waltz, G., et al., 2015. Variation in responses of fishes across multiple reserves within a network of marine protected areas in temperate waters. Plos One, 10: e0118502. doi: 10.1371/journal.pone. 0118502

Subsecretaría de Pesca y Acuicultura (SUBPESCA). 2018. Estados de situación de las principales pesquerías chilenas 2012-2018. SUBPESCA, Valparaíso.

Received: 4 August 2020; Accepted: 7 March 2021
Worm, B., Hilborn, R., Baum, J.K., Branch, T.A., Collie, J.S., Costello, C., et al. 2009. Rebuilding global fisheries. Science, 325: 578-585. doi: 10.1126/science. 1173146

Yáñez, E., González, A. \& Barbieri, M.A. 1995. Estructura térmica superficial del mar asociada a la distribución espacio-temporal de sardina y anchoveta en la zona norte de Chile entre 1987 y 1992. Investigaciones Marinas, Valparaíso, 23: 123-147. doi: $10.4067 / \mathrm{s} 0717-71781995002300008$ 